GEOLOGICAL SURVEY CIRCULAR 263

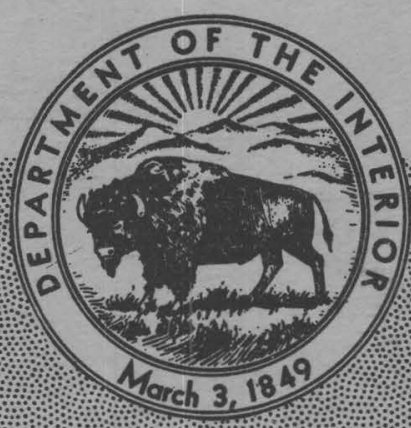

\title{
.
} $\operatorname{arch} 3,18$

\section{REPORTS AND MAPS OF \\ THE GEOLOGICAL SURVEY \\ RELEASED ONLY IN THE \\ OPEN FILES, 1952}





\author{
UNITED STATES DEPARTMENT OF THE INTERIOR \\ Douglas McKay, Secretary \\ GEOLOGICAL SURVEY \\ W. E. Wrather, Director
}

GEOLOGICAL SURVEY CIRCULAR 263

\title{
REPORTS AND MAPS OF THE GEOLOGICAL SURVEY RELEASED ONLY IN THE OPEN FILES, 1952
}

By Donald R. Wiesnet, Lois E. Randall, and Benjamin E. Jones 
- 


\title{
REPORTS AND MAPS OF THE GEOLOGICAL SURVEY RELEASED ONLY IN THE OPEN FILES, 1952
}

\author{
By Donald R. Wiesnet, Lois E. Randall, and Benjamin E. Jones \\ CONTENTS \\ Page \\ Introduction. ..................... 1 \\ Maps and reports...................... 1 \\ Index............................. 11 \\ INTRODUCTION
}

This circular contains a list of the maps and reports released by the Geological Survey in 1952 that are available only in open files. They may be consulted in the Geological Survey Library in Washington, D. C., and at various field offices, the addresses of which are given immediately after the date of the report. They may also be read at the offices of various cooperating agencies, as indicated.

Most of the maps were duplicated by rapid and inexpensive processes, such as photostat, vandyke, or ozalid, but some were printed by photolithography. Most of the texts for the reports are typed copies (ribbon or carbon copy), but some have been mimeographed. A few of these reports and maps were made available in limited quantities for distribution, as indicated in the list, and these may be obtained as long as the supply lasts.

The reports and maps of the Conservation Division concern the geology or the topography of federally owned or controlled lands as they affect the production of water power, oil, and gas; they cover areas studied and mapped by geologists and engineers in 4 States.

The reports and maps of the Geologic Division contain results of work accomplished by Survey geologists in 35 States, Alaska, the Virgin Islands, the Trust Territory of the Pacific, Honduras, Mexico, and Japan. These maps and reports are released in preliminary form in order to make information immediately available to property owners and mine operators concerned with exploration for and production of minerals, fuels, and construction materials.

The reports of the Water Resources Division contain information on streamflow, ground water, quality of water, and related geology and hydrology, in the United States, the Virgin Islands, the Trust Territory of the Pacific, and Japan.

A general index follows, in which the reader is referred to a report by its serial number as listed in the following list of reports, which are arranged alphabetically by names of the authors.

\section{MAPS AND REPORTS}

1. Agnew, A. F., Description of rock formations and minerals from holes drilled in Tete des Morts area, Iowa: 22p. Mar. 14, 1952. 108 Wisconsin Institute of Technology, Platteville, Wis.; 213 Science Hall, Madison, Wis.; Iowa Geological Survey, Geology Annex, Iowa City, Iowa.

2. Albers, J. P., Preliminary geologic map of the Bully Hill and Rising Star mines, Shasta County, Calif.: 2 maps. Mar. 14, 1952. 102 Old Mint Bldg., Fifth and Mission Sts., San Francisco, Calif.; California Division of Mines and Geology, Ferry Bldg., San Francisco, Calif.
3. Allen, W. B., Rhode Island cooperative groundwater survey report for 1951: 13 p., 5 figs. July 22, 1952. 101 Custom House Bldg., Providence, R. I.; 230 Old Country Rd., Mineola, L. I., N. Y.

4. Allen, W. B., Halberg, H. N., and Pistrang, M. A., Preliminary investigation of the groundwater resources of the Merrimack River drainage basin, N. H. and Mass.: 19 p. , 3 figs. July 22, 1952. 927 Post Office Bldg., Boston, Mass.; 230 Old Country Rd., Mineola, L. I., N. $Y$. 
5. Almond, Hy, A field method for the determination of traces of cobalt in soils: 6 p. May 26, 1952. 468 New Customhouse, Denver, Colo.; 504 Federal Bldg., Salt Lake City, Utah; 102 Old Mint Bldg., Fifth and Mission Sts., San Francisco, Calif.; South 157 Howard St., Spokane, Wash.

6. Arney, J. A., and Wilson, H. D., Jr., Water levels in observation wells in Santa Barbara County, Calif., in 1951: 20 p., 2 pls. Dec. 2, 1952. 2520 Marconi Ave., Sacramento, Calif.; 735 State St., Santa Barbara, Calif.

7. Arnow, Theodore, Ground-water investigations in the Trust Territory of the Pacific: 4 p., 6 figs. Jan. 21, 1952. Agana, Guam; 333 Federal Bldg., Honolulu, T. H.

8. Babcock, H. M., Memorandum on the groundwater resources of the Horse Creek and Cherry Creek drainage basins, Wyo.: 12 p., $1 \mathrm{fig}$. Oct. 7, 1952. 510 Rudge-Guenzel Bldg., Lincoln, Nebr.

9. Bailey, E. H., Eleven maps of the New Almanden quicksilver mine area, California. Jan. 23, 1952. 102 Old Mint Bldg., Fifth and Mission Sts., San Francisco, Calif.; California Division of Mines and Geology, Ferry Bldg., San Francisco, Calif.

10. Baker, A. A., and others, Geologic map of the area south of Park City, Utah. Juiy 15, 1952. 468 New Customhouse, Denver, Colo.; 504 Federal Bidg., Salt Lake City, Utah.

11. Bateman, A. F., Jr., and Erdmann, C. E., Geology of Big Bottom dam site, Lewis River, Wash.: 5 p., 1 map. June 19, 1952. 244 Federal Bldg., 'Tacoma, Wash. ; 619 Post Office Bldg. , Portland, Oreg.

12. Bates, C. E., Photogeologic maps of the Stinking Spring Creek 13 and 14 quadrangles, Emery County, Utah. Oct. 8, 1952. 468 New Customhouse, Denver, Colo.; Grand Junction, Colo.; 504 Federal Bldg., Salt Lake City, Utah.

13. Becraft, G. E., Geologic map of the Comet area, Jefferson City quadrangle, Jefferson County, Montana: 1 map with overlay sheet showing radioactive anomalies. Oct. 8, 1952. 504 Federal Bldg., Salt Lake City, Utah; South 157 Howard St., Spokane, Wash.; Montana Bureau of Mines and Geology, Butte, Mont.

14. Benedict, P. C., and Matejka, D. Q., The measurement of total sediment load in alluvial streams: 35 p. , 5 figs., 1 table. Dec. 29, 1952. 510 Rudge-Guenzel Bldg., Lincoln, Nebr.

15. Benedict, P. C., and others, Total sediment load measured in turbulence flue: 63 p., 25 figs. Dec. 22, 1952. 510 Rudge-Guenzel Bldg., Lincoln, Nebr.

16. Boucot, A. J., Traprock deposit in Somerset County, Maine: map. July 18, 1952. Maine Development Commission, Augusta, Maine; State Geologist, Orono, Maine.
17. Brashears, M. L., Ground-water situation in Japan: 40.p., 1 pl., 4 figs. Apr. 30, 1952.

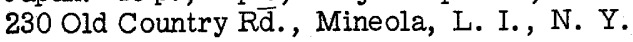

18. Britt, S. H., translator-Caillère, S., and Kraut, F., Le rôle de la mineralogie dans la construction des barrages [The role of mineralogy in the construction of dams], Génie civil, tome 128, no. 18 , p. $345-347$, 6 figs., Paris, 1951 [in French]: translation 32, 9 p., 2 figs. May 26, 1952. 468 New Customhouse, Denver, Colo. A limited number of copies of the translation have been mimeographed and, as long as the supply lasts, can be obtained by writing to the U. S. Geological Survey, Washington 25, D. C.

19. Broadhurst, W. L., Ground-water hydrology: 8 p. Dec. 30, 1952. 302 West 15th St., Austin, Tex.

20. Brown, R. H., Procedure for analyzing waterlevel records: 4 p., 1 fig. Jan. 21, 1952. 2209 General Services Bldg., Washington, D. C.

21. Burgess, C. E., Fourth progress report on the cooperative investigation of springs and streamflow in the Tecolote Tunnel area of Santa Barbara County, Calif.: 175 p., 2 pls. Oct. 22, 1952. 429-F Post Office Bldg., Los Angeles, Calif.; 541 Federal Office Bldg., San Francisco, Calif.

22. Cady, W. M., Quicksilver deposit near Aleknagik, Nushagak district, southwestern Alaska: 4 p., 3 figs. Aug. 25, 1952. 100 Old Mint Bldg., Fifth and Mission Sts., San Francisco, Calif.; Subport Bldg., Juneau, Alaska; Lavery Bldg., Fairbanks, Alaska; U. S. Bureau of Mines, Federal Bldg., Anchorage, Alaska.

23. Cheney, T. M., Peterson, J. A., Warner, M. A., Smart, R. A., Waring, R. G., and Sheldon, R. P., Stratigraphic sections of the Phosphoria formation measured and sampled in 1951: $71 \mathrm{p}$. of sections. Oct. 8, 1952. 504 Federal Bldg., Salt Lake City, Utah; South 157 Howard Street, Spokane, Wash.; Montana Bureau of Mines and Geology, Butte, Mont.; Idaho Bureau of Mines and Geology, Moscow, Idaho; Wyoming Geological Survey, Laramie, Wyo.

24. Coates, D. R., Geology of ground water in the Organ Pipe Cactus National Monument, Ariz.: 11 p., 1 map. Oct. 22, 1952. 18 East McCormick St., Tucson, Ariz.

25. Cobb, E. H., Preliminary report on coal investigations in the Homer district, Kenai coal field, Alaska, in 1950 and 1951: 19 p. Dec. 8, 1952. Alaskan Geology Branch, 100 Old Mint Bldg. , Fifth and Mission Sts., San Francisco, Calif.; Subport Bldg., Juneau, Alaska; Lavery Bldg., Fairbanks, Alaska; Territorial Department of Mines, Juneau, Alaska; U. S. Bureau of Mines, Federal Bldg., Anchorage,Alaska.

26. Conant, L. C., Origin of the Chattanooga shale: 22 p. Oct. 7, 1952. Alabama Geological Survey, University, Ala.; Kentucky Geological Survey, Lexington, Ky.; Division of Geology, State Office Bldg., Nashville, Tenn. 
27. Conover, C. S., Effect of development of ground water west of Red Mountain, N. Mex.: 53 p., 11 figs. Dec. 30, 1952. 218 Bass Bldg., 918 West Park Ave., Albuquerque, N. Mex.

28. Conover, C. S., Significance and presentation of annual measurements of ground-water levels in New Mexico: 5 p. July 22, 1952. 218 Bass Bldg., 918 West Park Ave., Albuquerque, N. Mex.

29. Crandell, D. R., Landslides in shale at Rapid City, S. Dak.: 17 p., 5 figs., 6 pls. Jan. 18, 1952. 468 New Customhouse, Denver, Colo.; State Geologist, University of South Dakota, Vermillion, S. Dak.; Library, South Dakota School of Mines, Rapid City, S. Dak.

30. Crandell, D. R., Preliminary report and maps on the geology of the Canning quadrangle, S. Dak.: 33 p., 1 map, cross section, 3 figs. Mar. 14, 1952. 468 New Customhouse, Denver, Colo.; State Geologist, University of South Dakota, Vermillion, S.. Dak.

31. Cressman, E. R., Geology of the Dry Valley quadrangle, Idaho: 12 p., 1 table. Aug. 25, 1952. 504 Federal Bldg., Salt Lake City, Utah; South 157 Howard St., Spokane, .Wash. ; Idaho Bureau of Mines and Geology, Moscow, Idaho.

32. Dennis, P. E., Ground-water recharge in the East Shore area, Utah: 17 p. March 26, 1952. 503-A Federal Bldg., Salt Lake City, Utah.

33. Dings, M. G. , Robinson, C. S., andBrock, M. R., Geologic map of Garfield quadrangle, Colo.: maps, sections, mine lists. Feb. 11, 1952. 468 New Customhouse, Denver, Colo.; 504 Federal Bldg., Salt Lake City, Utah; State Commissioner of Mines, State Museum Bldg., Denver, Colo.

34. Doolittle, R. N., Water power possibilities of the Red River and tributaries: 22 p., 1 map, 2 figs. May 17, 1951. 3240General Services Bldg., Washington, D. C.; Federal Center, Denver, Colo.

35. Doyel, W. W., Two cross sections showing sand and clay zones, Atascosa and Live Oak Counties, Tex.; and sand and clay zones, McMullen, Atascosa, and Karnes Counties, Tex.: July 22, 1952. 302 West 15th St., Austin, Tex.

36. Dunlap, J. C., Diamond-drill logs, Eve Mills zinc area, Monroe County, Tenn.: 32 logs. May 26, 1952. 13 Post Office Bldg., Knoxville, Tenn.; Division of Geology, State Office Bldg., Nashville, Tenn.

37. Durum, W. H. , Relationship of the mineral constituents in solution to streamflow, Saline River near Russell, Kans.: 17 p. May 12, 1952. 2204General Services Bldg., Washington, D. C.

38. Eakin, T. E., Water-resources investigation in the foreign assistance program: 7 p. May 28, 1952. 2209 General Services Bldg., Washington, D. C.
39. Eckhart, R. A., Report on haydite shale and argillite in the Matanuska Valley, Alaska: 31 p. Dec. 19, 1952. Alaskan Geology Branch, 100 Old Mint Bldg. , Fifth and Mission Sts., San Francisco, Calif.; Subport Bldg. , Juneau, Alaska; Lavery Bldg., Fairbanks, Alaska; Territorial Department of Mines, Juneau, Alaska; U. S. Bureau of Mines, Anchorage, Alaska. A limited number of copies have been mimeographed and; as long as the supply lasts, copies can be obtained by writing to the U. S. Geological Survey, Washington 25, D. C.

40. Eckstein, W. H. , Photogeologic map of Clay Hills 15 quadrangle, San Juan Country, Utah: Oct. 27, 1952. 468 New Customhouse, Denver, Colo.; Grand Junction, Colo. ; 504 Federal Bldg. , Salt Lake City, Utah.

41. Erdmann, C. E., Holmes, K. H., and Koskinen, B. K., Structure contour map of the Pondera oil field, Montana: 2 maps. May 7, 1952. 3240 GSA Bldg., Washington, D. C. ; 417 Electric Bldg., Great Falls, Mont.; 305 Federal Bldg., Casper, Wyo.

42. Fader, S. W., Records of wells and groundwater withdrawals for irrigation in Raft River valley, Cassia County, Idaho: 134 p., 1 pl., 1 fig. Jan. 22, 1952. All U. S. Geological Survey and U. S. Bureau of Reclamation offices in the Pacific Northwest; public libraries in southern Idaho and northern Utah; well drillers' associations in Idaho and Utah.

43. Fader, S. W., and Mower, R. W., Records of wells and ground-water levels in Minidoka County, Idaho: 173 p., 1 pl., 2 figs. Oct. 7, 1952. 209 Fidelity Bldg., Boise, Idaho.; 623 Post Office Bldg., Portland, Oreg. ; 204 Federal Bldg., Idaho Falls, Idaho.; 503-A Federal Bldg., Salt Lake City, Utah; Idaho State Reclamation Engineer, State House, Boise, Idaho.

44. Ferris, J. G., Ground-water conditions in the Alma area, Mich.: 3 p. Sept. 15, 1952. 612 Capitol Savings and Loan Bldg., 112 East Allegan St., Lansing, Mich.

45. Fischer, R. P., Base maps of a part of the Thompsons district, Grand County, Utah: 4 maps. May 26, 1952. 468 New Customhouse, Denver, Colo.; Library, Denver Federal Center, Denver, Colo.; Grand Junction, Colo.; 504 Federal Bldg., Salt Lake City, Utah; University of Utah, Salt Lake City, Utah.

46. Fischer, W. A., Photogeologic map of the Clay Hills 13 quadrangle, San Juan County, Utah: Oct. 8, 1952. 468 New Customhouse, Denver Colo.; Grand Junction, Colo.; 504 Federal Bldg., Salt Lake City, Utah.

47. Fischer, W. A., Photogeologic map of Clay Hills 12 quadrangle, San Juan County, Utah: Oct. 27, 1952. 468 New Customhouse, Denver, Colo.; Grand Junction, Colo. ; 504 Federal Bldg. , Salt Lake City, Utah. 
48. Flint, A. E., Description of rock formations and minerals from holes drilled in Highland area, Wisconsin: 24 p. Mar. 14, 1952. 108 Wisconsin Institute of Technology, Platteville, Wis.; 213 Science Hall, Madison, Wis.; Wisconsin Geological and Natural History Survey, 115 Science Hall, Madison, Wis.

49. Fraher, J. A., Engineering report on the Elk basin, Embar-Tensleep Reservoir, Wyo. and Mont.: 54 p., 16 figs., 4 tables. Oct. 1, 1952. 1033 General Services Bldg., Washington, D. C.; U. S. Geological Survey offices in Denver, Colo.; Billings, Mont.; Casper, Wyo.

50. George, W. O., Recharge of Texas' underground water reservoirs: 8 p. Aug. 15, 1952. 302 West 15th St., Austin, Tex.

51. Goddard, E. N., Structural control of fluorspar deposits in the Zuni Mountains, Valencia County, N. Mex.: 5 p., 1 fig. Jan. 23, 1952. Arizona Bureau of Mines, University of Arizona, Tucson, Ariz. ; and New Mexico Bureau of Mines and Mineral Resources, Socorro, N. Mex.

52. Good, S. E., and Campbell, A. B., Geologic map of the Twin Crags quadrangle; Idaho. July 15, 1952. 504 Federal Bldg., Salt Lake City, Utah; South 157 Howard St., Spokane, Wash.; Idaho Bureau of Mines and Geology, Moscow, Idaho.

53. Graham, J. B., The geological story of a river: 15 p., 4 figs. Jan. 21, 1952. Academy of Natural Sciences, 19th and Parkway, Philadelphia, Pa.

54. Griggs, A. B., Geologic maps of the north half of the Mullan and vicinity quadrangle, Idaho. May 26, 1952. 468 New Customhouse, Denver, Colo.; 504 Federal Bldg. , Salt Lake City, Utah; South 157 Howard Street, Spokane, Wash.

55. Griggs, A. B., Geology and notes on ore deposits of Canyon-Nine Mile Creeks area, Shoshone County, Idaho: 108 p., 23 pls. Oct. 27, 1952. South 157 Howard St., Spokane, Wash.; Idaho Bureau of Mines and Geology, Moscow, Idaho.

56. Gulbrandsen, R. A., McLaughlin, K. P., Honkala, F. S., Clabaugh, S. E., and Krauskopf, K. B., Geologic map and structure sections of the Johnson Creek quadrangle, Caribou County, Idaho: 2 sheets. - Aug. 25, 1952. 504 Federal Bldg., Salt Lake City, Utah; South 157 Howard Street, Spokane, Wash.; Idaho Bureau of Mines and Geology, Moscow, Idaho.

57. Hackman, R. J., Photogeologic map of the Agathla Peak 4 quadrangle, Navajo County, Ariz. Oct. 8, 1952. 468 New Customhouse, Denver, Colo.; Grand Junction, Colo.; Arizona Bureau of Mines, University of Arizona, Tucson, Ariz.

58. Hackman, R. J., Photogeologic maps of the Aneth $1,2,3,4,7$, and 8 quadrangles, Utah and Colorado. Aug. 25, 1952. 468 New Customhouse, Denver, Colo. ; 504 Federal Bldg. , Salt Lake City, Utah.
59. Hackman, R. J., Photogeologic maps of the Aneth 5 and 6 quadrangles, 'San Juan County, Utah. Oct. 8, 1952. 468 New Customhouse, Denver, Colo.;:Grand Junction, Colo.; 504 Federal Bldg., Salt Lake City, Utah.

60. Hackman, R. J., Photogeologic maps of the Elk Ridge 1 and 8 quadrangles, Utah. Oct. 27, 1952. 468 New Customhouse, Denver, Colo.; Grand Junction, Colo.; 504 Federal Bldg., Salt Lake City, Utah.

61. Hackman, R. J., Photogeologic maps of the Elk Ridge 9,13 , and 16 quadrangles, San Juan County, Utah. Aug. 25, 1952. 468 New Customhouse, Denver, Colo.; 504 Federal Bldg. , Salt Lake City, Utah.

62. Hackman, R. J., Photogeologic map of the Elk Ridge 12 quadrangle, San Juan County, Utah. Oct. 8, 1952. 468 New Customhouse, Denver, Colo.; Grand Junction, Colo.; 504 Federal Bldg., Salt Lake City, Utah.

63. Hackman, R. J., Photogeologic maps of the Verdure $1,2,4,6,7$, and 8 quadrangles, Utah and Colo. Oct. 27, 1952. $468 \mathrm{New}$ Customhouse, Denver, Colo.; Grand Junction, Colo.; 504 Federal Bldg., Salt Lake City, Utah.

64. Hackman, R. J., Photogeologic maps of the Verdure 3 and 5 quadrangles, San Juan County, Utah. Oct. 8, 1952. 468 New Customhouse, Denver, Colo.; Grand Junction, Colo.; 504 Federal Bldg., Salt Lake City, Utah.

65. Hackman, R. J., Photogeologic maps of the Verdure $9,10,11,12,13,14,15$, and 16 quadrangles, Utah and Colorado. Aug. 25, 1952. 468 New Customhouse, Denver, Colo.; 504 Federal Bldg., Salt Lake City, Utah.

66. Hackman, R. J., and Ray, R. G., Photogeologic maps of the Bluff 1,8 , and 13 quadrangles, San Juan County, Utah. Aug. 25, 1952. 468 New Customhouse, Denver, Colo.; 504 Federal Bldg., Salt Lake City, Utah.

67. Halpenny, L. C., and Cushman, R. L., Pumpage and ground-water levels in Arizona in 1951: 20 p. Nov. 18, 1952. 18 East McCormick St., Tucson, Ariz.; 4014 North 7th St., Phoenix, Ariz.

68. Halpenny, L. C., Cushman, R. L., and Feth, J. H., Answers to 24 questions asked by the Hon. John R. Murdock, Member of Congress from Arizona, by letter of December 7, 1951, to the Director, U. S. Geological Survey: 20 p. Mar. 26, 1952. 18 East McCormick St., Tucson, Ariz.

69. Halpenny, L. C., and others, Map of Safford Valley, Graham County, Ariz., showing location of irrigation wells as of August 30, 1952. Dec. 2, 1952. 18 East McCormick St., Tucson, Ariz.; P. O. Box 517, Holbrook, Ariz. 
70. Hartshorn, J. H., Geologic reconnaissance along the proposed location of Route 128 in Newton and Norwood quadrangles, Mass.: 5 p., 1 map. Oct. 27, 1952. Barnum Museum, Tufts College, Medford, Mass.; Massachusetts Department of Public Works, 100 Nashua St., Boston, Mass.

71. Hastings, W. W., Chemistry of natural water: 11 p. Oct. 1, 1952. 2204 General Services Bldg., Washington, D. C.

72. Heinrich, W. E., Crystal Clear mica mine, Randolph County, Ala.: map. July 28, 1952. 13 Post Office Bldg., Knoxville, Tenn.; Geological Survey of Alabama, University, Ala.

73. Henderson, J. R., Preliminary total intensity aeromagnetic map of part of the Somerville quadrangle, N. J. Mar. 3, 1952. State Geologist, Room 108, 520 East State St., Trenton, N. J.; Department of Geology, 101 Rutgers University, New Brunswick, N. J.; Geology Department Library, Guyot Hall, Princeton University, Princeton, N. J.; Public Library, 31 East Clinton St., Dover, N. J. ; Morristown Library, Morristown, N. J.

74. Henderson, J. R., Preliminary total intensity aeromagnetic maps of part of Grays Harbor, Pacific, Thurston, and Lewis Counties, Wash.: 2 maps. Sept. 15, 1952. 623 Post Office Bldg. , Portland, Oreg.; 2520 Marconi Ave., Sacramento, Calif.; Room 206, 10929 Weyburn Ave., Los Angeles, Calif.; 234 Federal Bldg., Tulsa, Okla.; 504 Federal Bldg., Salt Lake City, Utah; Division of Mines and Geology, State Department of Conservation and Development, 404 Transportation Bldg., Olympia Wash.

75. Herrick, S. M., Results of chloride determinations of water samples from observation wells in the Savannah area, Ga., October 1952: 10 p., 8 figs. Dec. 30, 1952. 11 Hunter St., Atlanta, Ga.

76. Howard, C. S., Quality of Colorado River water: 8 p. Jan. 15, 1952. P. O. Box 2657, Bldg. 504, Fort Douglas, Salt Lake City, Utah.

77. Howard, C. S., Effects of irrigation on water quality: 4 p. Sept. 26, 1952. P. O. Box 2657, Blig. 504, Fort Douglas, Salt Lake City, Utah.

78. Hoy, N. D., Two maps of Dade County, Fla., showing approximate position of the 1,000-ppm isochlor as of 1951 and approximate area of potential salt-water penetration under 1945 conditions. Feb. 12, 1952. Dinner Key, South Bayshore Dr., Miami, Fla.

79. Hoy, N. D., Map of Dade County, Fla., showing the approximate average annual water levels for 1945. Mar. 26, 1952. Dinner Key, South Bayshore Dr., Miami, Fla.

80. Hoy, N. D., Two maps of Dade County, Fla., showing the average annual water levels, 1950, and the approximate average water levels for the period 1940-1950. May 28, 1952. Dinner Key, South Bayshore Dr., Miami, Fla.
81. Hubbell, D. W., Matejka, D. Q., and Colby, B. R., Progress report-Investigations of fluvial sediments of the Snake River near Burdge, Nebr.: 43 p., 14 figs. May 28, 1952. 510 Rudge-Guenzel Bldg., Lincoln, Nebr.

82. Jensen, F. S., Preliminary report on the geology of the Nashua quadrangle, Mont.: 37 p., map, 6 figs. Feb. 8, 1952. 468 New Customhouse, Denver, Colo.; Montana Bureau of Mines and Geology, Montana School of Mines, Butte, Mont.

83. Jensen, F. S., Structural contour map of part of the Williston basin in the Fort Peck district, Montana. May 19, 1952. 468 New Customhouse, Denver, Colo.; 315 Federal Bldg., Billings, Mont.; Montana Bureau of Mines and Geology, Butte, Mont.

84. Johnson, A. I., The Lincoln hydrologic laboratory, Lincoln, Nebr.: 10 p., 11 figs. Aug. 15, 1952. 510 Rudge-Guenzel Bldg., Lincoln, Nebr.

85. Jones, P. H., Electric-logging methods, principles of interpretation, and application in ground-water studies: 45 p., 18 figs. Aug. 15, 1952. 16 Geology Bldg., University of Louisiana, Baton Rouge, La.

86. Kammerer, J. C., and Graham, J. B., Groundwater resources of the United States Naval Base, Philadelphia, Pa.: 137 p., 31 figs. Oct. 22, 1952. Academy of Natural Sciences, 19th St. and Parkway, Philadelphia, Pa.

87. Klepper, M. R., Weeks, R. A., and Ruppel, E. T., Geology of the southern Elkhorn Mountains, Jefferson and Broadwater Counties, Mont.: 6 maps, 13 secs. Oct. 8, 1952. 504 Federal Bldg., Salt Lake City, Utah; South 157 Howard St., Spokane, Wash.; Montana Bureau of Mines and Geology, Butte, Mont.; Public Library, Helena, Mont:

88. Lamar, W. L., Chemical and physical character of brines from the Dundee formation: $17 \mathrm{p}$., 7 tables. June 24, 1952. 2822 East Main St., Columbus, Ohio.

89. Lamar, W. L., and Laird, L. B., Determination of sodium and potassium in water using the Perkin-Elmer flame photometer, model 52A: 14 p. Jan 10, 1952. 2822 East Main St., Columbus, Ohio.

90. LaMoreaux, P. E., Portable submersible pumping unit: 5 p., 3 pls., 2 figs. May 28, 1952. Smith Hall, Geology Bldg., University of Alabama, Tuscaloosa, Ala.

91. LaRocque, G. A., Jr., Graphic method for plotting field pumping-test data: 4 p. , 3 figs. July 22, 1952. 510 Rudge-Guenzel Bldg.,

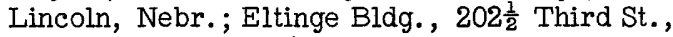
Bismarck, N. Dak.

92. Lemke, R. W., Preliminary map of glacial Lake Souris, North Dakota. May 2, 1952. 468 New Customhouse, Denver, Colo.; State Geologist, Grand Forks, N. Dak. 
93. Loeltz, O. J., Ground-water conditions in the vicinity of The Strip, Las Vegas Valley, Clark County, Nev., 1952: 14 p., 1 pl., 1 fig. Dec. 2, 1952. 231 State Office Bldg., 201 South Fall St., Carson City, Nev.; Office of the State Engineer, Carson City, Nev.

94. Lovering, T. G., Geology of the western portion of the Santa Rita quadrangle, Grant County, N. Mex.: 44 p., 1 illus. Nov. 24, 1952. Silver City, N. Mex.; New Mexico Bureau of Mines and Mineral Resources, Socorro, N. Mex.

95. McGuinness, C. L., Ground water in the vicinity of the San Manuel copper mine, Pinal County, Ariz. (letter of Sept. 23, 1952, from Director, U. S. Geological Survey, to Mr. Harry A. McDonald, Administrator, Reconstruction Finance Corporation): 6 p. Dec. 30, 1952. 18 East McCormick St., Tucson, Ariz.

96. Maclay, R. W., Occurrence of ground water in the Cheyenne River and Standing Rock Indian Reservation areas, N. and S. Dak.: 95 p., 2 pls., 2 figs. Aug. 15, 1952. 510 RudgeGuenzel Bldg., Lincoln, Nebr.; P. O. Box 1412, Huron, S. Dak.

97. Malmberg, G. T., Progress report, Huntsville project, Ala.: 3 p., 3 figs. Oct. 22, 1952. Smith Hall, Geology Bldg., University of Alabama, Tuscaloosa, Ala.

98. Meyer, R. R., Geology and hydrology of dam sites on the island of St. Croix, V. I.: 66 p., 4 figs. Jan. 21, 1952, 2209 General Services Bldg., Washington, D. C.

99. Meyers, J. D., and Newcomb, R. C., Geology and ground-water resources of the Swan LakeYonna Valleys area, Klamath County, Oreg.: 151 p., 10 pls. Dec. 8, 1952. 623 Post Office Bldg., Portland, Oreg.; Office of the State Engineer, Salem, Oreg.; Klamath County Agricultural Agent, Klamath Falls, Oreg.; main public libraries of Klamath County, Oreg.

100. Moore, J. G., Geology of the Mount Rosa area, Nevada: 85 p., 78 illus. Oct. $8,1952.504$ Federal Bldg., Salt Lake City, Utah; Nevada Bureau of Mines, 201 Mackay School of Mines Bldg., University of Nevada, Reno, Nev.

101. Morris, D. A., and Hackett, O. M., Progress report on the geology and ground-water hydrology of the Riverton irrigation project, Wyo., with a section on the chemical quality of the water by W. H. Durum: 208 p., 2 pls., 14 figs. Feb. 14, 1952. 510 Rudge-Guenzel Bldg., Lincoln, Nebr.; 301 Federal Recreation Bldg., Cheyenne, Wyo.; 205 Post Office Bldg., Riverton, Wyo. ; 318 Post Office Bldg., Billings, Mont.; Bureau of Reclamation offices at Riverton, Wyo.; Billings, Mont.; and Cody, Wyo.

102. Morris, R. H., Heavy-mineral analysis of sedimentary rocks of northern Alaska: $68 \mathrm{p}$. (incl. 30 p. of tables), 6 illus. July 15, 1952. 4215 General Services Bldg., Washington, D. C.
103. Moxham, R. M., Pumice deposits in the Alaska Peninsula-Cook Inlet region: 21 p. Jan. 21, 1952. Alaskan Geology Branch, 100 Old Mint Bldg., 5th and Mission Sts., San Francisco, Calif.; Subport Bldg., Juneau, Alaska; Lavery Bldg., Fairbanks, Alaska; U. S. Bureau of Mines, Anchorage, Alaska. A limited number of copies have been mimeographed, and as long as the supply lasts, copies can be had by writing the U. S. Geological Survey, Washington 25, D. C.

104. Moxham, R. M., and Eckhart, R. A., Preliminary report on the occurrence of lime marl in the Wasilla area, Alaska: 19 p. Dec. 22, 1952. 100 Old Mint Bldg., Fifth and Mission Sts., San Francisco, Calif.; Subport Bldg., Juneau, Alaska; Lavery Bldg., Fairbanks, Alaska; U. S. Bureau of Mines, Anchorage, Alaska; Territorial Department of Mines, Juneau, Alaska.

105. Myers, W. B., Geology and mineral deposits of the northwest quarter of Willis quadrangle and adjacent Browns Lake area, Beaverhead County, Mont.: 46 p., 2 maps. July 28, 1952. South 157 Howard St., Spokane, Wash.; Montana Bureau of Mines and Geology, Butte, Mont.; Idaho Bureau of Mines and Geology, Moscow, Idaho.

106. Nace, R. L., Records of wells and springs in western Oneida County, Idaho: 51 p., 1 pl., 1 fig. Aug. 18, 1952. 209 Fidelity Bldg., Boise, Idaho; 623 Post Office Bldg., Portland, Oreg.; 204 Federal Bldg., Idaho Falls, Idaho; 503-A Federal Bldg., Salt Lake City, Utah; Idaho State Reclamation Engineer, State House, Boise, Idaho.

107. Neuschel, S. K., A memorandum report on four manganese claim groups near Socorro, N. Mex.: 6 p., 2 figs. May 26, 1952. 468 New Customhouse, Denver, Colo.; and New Mexico Bureau of Mines and Mineral Resources, Socorro, N. Mex.

108. Newhouse, W. H., and Hagner, A. F., Preliminary report on the titaniferous iron deposits of the Laramie Range, Wyo.: 45 p., 2 maps, 15 cross sections. May 26, 1952. 468 New Customhouse, Denver, Colo.; Geological Survey of Wyoming, Laramie, Wyo. (Jan. 16, 1951); 504 Federal Bldg., Salt Lake City, Utah (Dec. 27, 1951).

109. Olson, J. C., Preliminary report and geologic map of the Mountain Pass district, San Bernardino County, Calif.: 5 p., 1 map. Mar. 14, 1952. 468 New Customhouse, Denver, Colo.; 504 Federal Bldg., Salt Lake City, Utah; 102 Old Mint Bldg., Fifth and Mission St., , San Francisco, Calif.; California Division of Mines and Geology, Ferry Bldg., San Francisco, Calif.

110. Olson, J. C., Geologic setting of the Mountain Pass rare earth deposits, San Bernardino County, Calif.: 109 p., 8 pls. Oct. 27, 1952. 102 Old Mint Bldg., Fifth and Mission Sts., San Francisco, Calif.; California Division of Mines and Geology, Ferry Bldg., San Francisco, Calif. 
111. O'Malley, F. W., Davidson, D. F., Hoppin, R. A., and Sheldon, R. P., Stratigraphic sections of the. Phosphoria formation in Idaho (third Idaho report): 39 p. Apr. 25, 1952. 504 Federal Bldg., Salt Lake City, Utah; South 157 Howard St., Spokane, Wash.; Montpelier, Idaho; Idaho Bureau of Mines and Geology, Moscow, Idaho; Montana Bureau of Mines and Geology, Butte, Mont.; Wyoming Geological Survey, Laramie, Wyo.; University of Utah, Salt Lake City; Utah.

112. Perlmutter, N. M., and Lusczynski, N. J., Deep artesian observation well at Plainview, Nassau County, Long Island, N. Y.: 5 p. , 5 figs. April 17, 1952. 230 Old Country Rd., Mineola, L. I., N. Y.

113. Peterson, N. P., Geologic map of the Globe quadrangle, Ariz.: 1 map in 2 parts, 4 cross sections. May 26, 1952. Globe, Ariz.; Arizona Bureau of Mines, University of Arizona, Tucson, Ariz.

114. Poiré, I. V., translator-Nersesova, Z. A., [Concerning the melting of ice in the ground at negative temperatures], Akad. Sci. USSR Doklady, Comptes Rendus, tome 79, no. 3, p. 507-508, table, fig., Moscow, 1951 [in Russian]; Vinokurov, G. A., [Contribution to the problem of the capacity of water for spontaneous crystallization], Vsesoyuz. Arktich. Inst. Trudy, tome 100, p. 39-41, Leningrad, 1938 [in Russian]: 3p. July 15, 1952. $468 \mathrm{New}$ Customhouse, Denver, Colo.; 504 Federal Bldg. , Salt Lake City, Utah; Alaskan Geology Branch, 100 Old Mint Bldg., Fifth and Mission Sts., San Francisco, Calif.; Subport Bldg. , Juneau, Alaska; Water Resources Division, Lavery Bldg. , Fairbanks, Alaska; U. S. Bureau of Mines, Federal Bldg., Anchorage, Alaska.

115. Pree, H. L., Jr., and Walker, W. H., Memorandum on the geology and ground-water resources of the Calvert City-Gilbertsville area, Marshall County, Ky.: 13 p., 2 figs. Feb. 12, 1952. 531 Federal Bldg., Louisville, Ky. ; Office of Agricultural and Industrial Development Board of Kentucky, Frankfort, Ky.

116. Rasmussen, W. C., and Haigler, L. B., Groundwater problems in highway construction and maintenance: 42 p., 8 figs. Dec. $30,1952$. Brown St., Salisbury, Md.; Delaware State Highway Dept., Dover, Del.

117. Ray, R. G., Photogeologic map of Setsiltso Springs 3 quadrangle, Apache County, Ariz. Oct. 27, 1952. 468 New Customhouse, Denver, Colo.; Grand Junction, Colo.; 504 Federal Bldg., Salt Lake City, Utah; Arizona Bureau of Mines, University of Arizona, Tucson, Ariz.

118. Ray, R. G., Photogeologic map of Setsiltso Springs 4 quadrangle, Apache County, Ariz. Nov. 24, 1952. 468 New Customhouse, Denver, Colo.; Grand Junction, Colo.; Arizona Bureau of Mines, University of Arizona, Tucson, Ariz.
119. Ray, R. G., Photogeologic map of Setsiltso Springs 5 quadrangle, Apache County, Ariz. Oct. 27, 1952. 468 New Customhouse, Denver, Colo.; Grand Junction, Colo.; Arizona Bureau of Mines, University of Arizona, Tucson, Ariz.

120. Ray, R. G., Photogeologic map of the Agathla Peak 8 quadrangle, Navajo County, Ariz. Nov. 24, 1952. 468 New Customhouse, Denver, Colo.; Grand Junction, Colo.; Arizona Bureau of Mines, University of Arizona, Tucson, Ariz.

121. Ray, R. G., Photogeologic map of Bluff 14 quadrangle, San Juan County, Utah. Oct. 27, 1952. 468 New Customhouse, Denver, Colo.; Grand Junction, Colo.; 504 Federal'Bldg., Salt Lake City, Utah.

122. Ray, R. G., and Fischer, W. A., Photogeologic maps of the Stinking Spring Creek 11 and 12 quadrangles, Emery County, Utah. Aug. 25, 1952. 468 New Customhouse, Denver, Colo.; 504 Federal Bldg., Salt Lake City, Utah.

123. Reade, H. L., Jr., Progress report, Montgomery project, Ala.: 5 p., 2 figs. Oct. 22, 1952. U. S. Geological Survey, Smith Hall, Geology Bldg., University of Alabama, Tuscaloosa, Ala.

124. Reed, E. W., Memorandum on decline of water levels in West Denton area, Md., adapted from earlier memorandum by W. C. Rasmussen: 5 p., 1 fig. Oct. 22, 1952. Brown St., Salisbury, Md.; Maryland Dept. Geology, Mines, and Mineral Resources, Johns Hopkins University, Baltimore, Md.

125. Remson, Irwin, Results of pumping test at Seabrook Farms, N. J., Jan. 16-19, 1951: 27 p., 2 figs. Aug. 15, 1952. 430-432 Federal Bldg., Trenton, N. J.

126. Riggs, H. C., Streamflow depletion and recession characteristics of Columbia River tributaries: 171 p., 6 figs. Dec. 30, 1952. 408 Federal Bldg., Helena, Mont.; 429 Federal Bldg. , Boise, Idaho; 632 Post Office Bldg., Portland, Oreg.

127. Richards, P. W., Structural geology of the Crazy Mountain syncline-Beartooth Mountain border east of Livingston, Mont.: 77 p., 17 illus. July 28, 1952. 315 Federal Bldg., Billings, Mont.; 468 New Customhouse, Denver, Colo.; Library, Cornell University, Ithaca, N. Y.

128. Roberts, R. J., Honduras, El Quezal mine (antimony): 8 p., 3 figs. Apr. 25, 1952. 468 New Customhouse, Denver, Colo.

129. Roberts, W. A., and Gude, A. J., 3d, Uraniumbearing deposits west of Clancy, Jefferson County, Mont.: 30 p., 7 figs., 1 table. Mar. 14, 1952. South 157 Howard St., Spokane,Wash. ; Montana Bureau of Mines and Geology, Butte, Mont.; Helena Public Library, Helena, Mont. 
130. Robinson, T. W., Investigation of the water resources of the Nevares property in Death Valley National Monument, Calif.: 21 p., 1 fig. Feb. 12, 1952. 231 State Office Bldg. , 201 South Fall St., Carson City, Nev.

131. Rogers, C. L., Ulloa, S., and Tavera, E., Phosphate deposits of the Concepcion del Oro district, Zacatecas, Mexico: $11 \mathrm{p}$. Apr. 25, 1952. 468 New Customhouse, Denver, Colo.; American Embassy, Mexico, D. F., Mex.

132. Rosier, A. J., Reconnaissance of the geology and ground-water hydrology of the Belle Fourche irrigation project, S. Dak.: 34 p., 2 pls., 7 figs. Feb. 12, 1952. 510 RudgeGuenzel Bldg., Lincoln, Nebr.

133. Rothrock, H. E., Descriptions of cores from seventy-five wells in the Scurry Reef, Scurry County, Tex.: 186 p., 2 maps. Aug. 22, 1952. Off-Campus Research Center, Austin, Tex.; Midland County Library, Midland, Tex.; Bureau of Economic Geology, University of Texas, Austin, Tex.

134. Sainsbury, C. J., Preliminary report on the Nelson and Radovan copper projects, Nizina district, Alaska: 20 p. Dec. 3, 1952. Alaskan Geology Branch, 100 Old Mint Bldg., Fifth and Mission Sts., San Francisco, Calif.; Subport Bldg., Juneau, Alaska; Lavery Bldg., Fairbanks, Alaska.

135. Sceva, J. E., Geologic map of the southeastern part of the Point Misery quadrangle, Wash.: Sept. 15, 1952. 2128 South 38th St., Tacoma, Wash.

136. Schmidt, R. G., and Dutton, C. E., Progress report on geologic study of the Crosby and Ironton area of the Cuyuna Range, Crow Wing County, Minn.: 6 maps, 3 cross sections. June 24, 1952. 2 Crosby Theater Bldg., Crosby, Minn. ; 213 Science Hall, Madison, Wis.; Minnesota Geological Survey, Pillsbury Hall, University of Minnesota, Minneapolis, Minn.

137. Sharp, W. N., and Pray, L. D., Geologic map of bastnaesite deposits of the Birthday claims, San Bernardino County, Calif.: Mar. 14, 1952. 468 New Customhouse, Denver, Colo. ; 504 Federal Bldg., Salt Lake City, Utah; 100 Old Mint Bldg., Fifth and Mission Sts., San Francisco, Calif.; California Division of Mines and Geology, Ferry Bldg., San Francisco, Calif.

138. Shoemaker, E. M., Preliminary geologic map of part of the Sinbad Valley-Fischer Valley anticline, Colorado and Utah; Structure map and sections of the Sinbad ValleyFischer Valley anticline, Colorado and Utah. Aug. 25, 1952. 468 New Customhouse, Denver, Colo.; 504 Federal Bldg., Salt Lake City, Utah.

139. Smith, R. C., Water supply of the United States Fish Culture Station, White Sulphur Springs, W. Va.: 19 p. Mar. 26, 1952. 405 Industries Bldg., Morgantown, W. Va.
140. Smith, W. O., Upson, J. E., and others, Preliminary report on the Passamaquoddy bedrock survey, July-August 1951: 110 p., 2 pls., 24 figs. Dec. 30, 1952. 2209 General Services Bldg., Washington, D. C.

141. Staatz, M. H., and Trites, A. F., Geology of the Quartz Creek pegmatite district, Gunnison, Colo.: 166 p., 28 illus., 20 tables. July 15, 1952. 468 New Customhouse, Denver, Colo.; 504 Federal Bldg., Salt Lake City, Utah; and Columbia University Library, New York, N. Y:

142. Stallman, R. W., Apparatus for testing the permeability of samples in unconsolidated sediments, revision of earlier report by $\mathrm{V}$. C. Fishel and V. T. Springfield: 11 p., 2.figs. Jan. 21, 1952. 2209 General Services Bldg., Washington, D. C.

143. Stewart, J. W., Nace, R. L., and Deutsch, Morris, Preliminary report on ground water in the Michaud Flats Project, Power County, Idaho: 40 p., 2 pls., 2 figs. Jan. 26, 1952. 209 Fidelity Bldg., Boise, Idaho; 623 Post Office Bldg., Portland, Oreg.; 204 Federal Bldg., Idaho Falls, Idaho; Idaho State Reclamation Engineer, State House, Boise, Idaho; Bureau of Reclamation, Fair Grounds, Boise, Idaho.

144. Sundstrom, R. W., Ground water for irrigation at the Federal Correctional Institution, La Luna, Tex.: 11 p., 2 figs. Feb. 12, 1952. 302 West 15th St., Austin, Tex.

145. Swenson, F. A., Work of the Ground Water Branch, U. S. Geological Survey (talk given to members of Geology and Forestry Departments of University of Montana, Dec. 7, 1951): 11 p. Mar. 26, 1952. 318 Federal Bldg., Billings, Mont.

146. Swenson, H. A., Geochemical relationships of water in the Powder River basin, Wyo. and Mont.: 11 p. July 18, 1952. 510 Rudge-Guenzel Bldg. , Lincoln, Nebr.

147. Taylor, G. H., The ground-water resources of Nebraska: 9 p. Jan. 21, 1952. 510 RudgeGuenzel Bldg., Lincoln, Nebr.

148. Taylor, G. H., prepared under the direction of, Map of the Valentine National Wildlife RefugeAinsworth area, Nebr., showing location of wells, depth to water, and contours of the water table: Feb. 28, 1952. 510 Rudge-Guenzel Bldg., Lincoln, Nebr.; Office of Area Engineer, Bureau of Reclamation, Ainsworth, Nebr.

149. Thomas, H. E., A hydrogeologic problem in the proposed Echo Park Reservoir, Colo.: 11 p., 2 figs. Dec. 30, 1952. 503-A Federal Bldg., Salt Lake City, Utah.

150. Thomas, H. E., Index well in Ogden Valley, Utah: 33 p., 7 figs. Dec. 30, 1952. 503-A Federal Bldg., Salt Lake City, Utah.

151. Thomas, H. E., and Wilson, M. T., Determination of total evapotranspiration in Ashley Valley, Utah, by the inflow-outflow method: 21 p., 5 figs. May 28, 1952. 503-A Federal Bldg. , Salt Lake City, Utah. 
152. Thomasson, H. G., Summary of ground-water pumpage, recharge from Putah Creek, and fluctuations of ground-water levels in the Putah area, Calif.: 6 p. Dec. 30, 1952. 2520 Marconi Ave., Sacramento, Calif.

153. Thompson, R. M., and White, V. L., Geology of the Conant Creek-Muskrat Creek area, Fremont County, Wyo.: map. Oct. 27, 1952. 468 New Custom house, Denver, Colo. ; 315 Federal Bldg., Billings, Mont. ; 305 Federal Bldg., Casper, Wyo.; Wyoming Geological Survey, University of Wyoming, Laramie, Wyo.

154. Thurston, W. R., Pegmatites of the Crystal Mountain district, Larimer County, Colo.: 156 p., 44 illus., 17 tables. July 15, 1952. 468 New Customhouse, Denver, Colo.; 504 Federal Bldg., Salt Lake City, Utah; Columbia University Library, New York, N. Y.

155. Tolbert, G. E., Photogeologic maps of the Carlisle 1, 8, 9, and 16 quadrangles, San Juan Count ${ }_{5}$, Utah. Aug. 25, 1952. 468 New Customhouse, Denver, Colo.; 504 Federal Bldg., Salt Lake City, Utah.

156. Tolbert, G. E., Photogeologic maps of the Mount Peale 5, 6, 11, 12, and 14 quadrangles, San Juan County, Utah. Aug. 25, 1952. 468 New Customhouse, Denver, Colo.; 504 Federal Bldg. , Salt Lake City, Utah.

157. Tolbert, G. E., Photogeologic map of the Mount Peale 13 quadrangle, San Juan County, Utah. Oct. 8, 1952. 468 New Customhouse, Denver, Colo.; Grand Junction, Colo.; 504 Federal Bldg., Salt Lake City, Utah.

158. Troxell, H. C., and Wilson, H. D., Jr., Stream runoff and ground-water storage capacity, Santa Ynez River, Santa Barbara County, Calif.: 151 p. , 9 pls., 17 figs. Oct. 22, 1952. 429-F U. S. Post Office and Courthouse Bldg. , Los Angeles, Calif.; 2520 Marconi Ave., Sacramento, Calif.; 433 Balboa Bldg., 735 State St., Santa Barbara, Calif.

159. Turner, S. F., and Feth, J. H., Notes on springs along the Mogollon Rim, Ariz.: 16 p. April 17, 1952. 18 East McCormick St., Tucson, Ariz.

160. Twenhofel, W. S., Geology of the Alaska-Juneau lode system, Alaska: 175 p., illus. Oct. 27, 1952. 100 Old Mint Bldg., Fifth and Mission Sts., San Francisco, Calif.; Subport Bldg., Juneau, Alaska; University of Wisconsin Library, Madison, Wis.

161. Vitaliano, C. J., Geologic map of the Victor tungsten deposit, Granite, Nye County, Nev.: Aug. 25, 1952. 100 Old Mint Bldg., Fifth and Mission Sts., San Francisco, Calif.; 504 Federal Bildg., Salt Lake City, Utah; University of Nevada, 201 Mackay School of Mines Bldg., Reno, Nev.

162. Wallace, R. E., Hobbs, S. W., Rainey, H. C., and Bowyer, B., Geologic map of the Pottsville quadrangle, northern Idaho. Apr. 18, 1952. 504 Federal Bldg., Salt Lake City, Utah; South 157 Howard St., Spokane, Wash.; Idaho Bureau of Mines and Geology, Moscow, Idaho.
163. Walton, W. C., and Drescher, W. J., Improvements made on the use of type curves: $2 \mathrm{p}$., $1 \mathrm{fig}$. Jan. 21, 1952. 116 Science Hall, University of Wisconsin, Madison, Wis.

164. Warren, C. R., and Crandell, D. R., Preliminary report on geology of part of the Chamberlain quadrangle, S. Dak.: 45 p., 1 map. Oct. 27, 1952. 468 New Customhouse, Denver, Colo.; Library, Federal Center, Denver, Colo.; 504 Federal Bldg., Salt Lake City, Utah; Fuels Branch, Billings, Mont.; State Geologist, University of South Dakota, Vermillion, S. Dak.; Montana Bureau of Mines and Geology, Butte, Mont.

165. Wedow, Helmuth, White,M. G., and Moxham, R. M., Interim report on an appraisal of the uranium possibilities of Alaska: 124 p. , 8 figs. July 16, 1952. Alaskan Geology Branch, Subport Bldg., Juneau, Alaska; Lavery Bldg., Fairbanks, Alaska; Water Resources Division, Palmer, Alaska; 100 Old Mint Bldg., Fifth and Mission Sts., San Francisco, Calif.; Territorial Department of Mines, Anchorage, Alaska.

166. Weigle, J. M., Ground water: 8 p. Dec. 30 , 1952. 2128 South 38th St., Tacoma, Wash.

167. West, W. S., Reconnaissance for a uranothorianitebearing lode in the vicinity of the headwaters of the Peace River, Candle quadrangle, Seward Peninsula, Alaska: 12p., 1 fig. Oct. 27, 1952. Alaskan Geology Branch, Subport Bldg. , Juneau, Alaska; Lavery Bldg., Fairbanks, Alaska; Territorial Department of Mines, Juneau, Alaska; College, Alaska; Ketchikan, Alaska; and Nome, Alaska.

168. Wilson, H. D., Jr., Water levels in observation wells in Santa Barbara County, Calif., in 1950: 53 p., 1 pl. Jan. 21, 1952. 433 Balboa Bldg., Santa Barbara, Calif.; 2520Marconi Ave., Sacramento, Calif.

169. Wright, J. C., A magnetic anomaly near Bear Lake, Houghton County, Mich.: 7 p., 2figs. Apr. 25, 1952. Community Bldg., Houghton, Mich. ; Red Jacket Rd. and Mine St., Calumet, Mich.; 213 Science Hall, University of Wisconsin, Madison, Wis. ; Dept. of Geology, Michigan College of Mines and Technology, Houghton, Mich.; Geological Survey Division, Michigan State Department of Conservation, Lansing, Mich.

170. Anonymous, Arkansas bauxite logs, in Saline and Pulaski Counties, Ark.: over 6, 000 drill holes (on microfilm). Aug. 23, 1952. 221 West Third St., Joplin, Mo.; State Geologist, State Capitol, Little Rock, Ark.

171. Anonymous, Technical indexes in paleontology: Compendium of paleobotanical species (28 microfilm rolls; 135,490 images).

Paleobotanical bibliographical index (5 microfilm rolls; 17, 356 images).

Mesozoic species index-North and Central America, including the Caribbean ( 8 microfilm rolls; 25, 459 images).

Mesozoic species index-South America (3 microfilm rolls; 8,345 images).

Cushman catalog of Foraminifera (33 microfilm rolls; 118, 967 images).

Apr. 24, 1952. 1028 General Serviceș Bldg., Washington, D. C. 

Report

Alabama:

Geology, Chattanooga shale--------- 26

Ground water, Huntsville project---- 97 Montgomery project-_....... 123 Mica:

Randolph County, Crystal Clear mine-_......... 72

Alaska:

Coal, Kenai Field, Homer district---

Copper, Nizina district, Nelson and

Radovan projects-_-_-_-_---- 134

Gold, Alaska-Juneau lode system----- 160

Haydite shale and argillite, Mata-

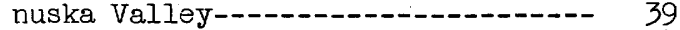

Lime marl, Wasilla area-.......-.- 104

Mercury, Nushagak district--.-_-.-- 22

Pumice, Alaska Peninsula-Cook Inlet

region-_-_-_.-_..- 103

Sedimentary rocks, heavy-mineral

analysis, northern part----------- 102

Uranothorianite, Seward Peninsula--- 167

Uranium possibilities-.-.-.-.-.-.-- 165

Apparatus:

Permeability testing, uncon-

solidated sediments-_-.-_-_-_-_- 142

Submersible pumping unit, portable-- 90

Arizona:

Ground water-1.-.-- 68

Organ Pipe Cactus National

Monument-_._- 24

pumpage and levels-_-_-_-_-_-- 67

San Manuel mine vicinity, Pinal

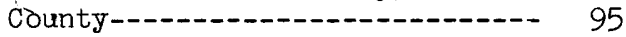

Maps and charts, geologic, Globe

quadrangle-..--_._-_.-. 113

irrigation wells, Safford Valley- 69 photogeologic, Apache County,

quadrangles Setsiltso

Springs 3-5----------117-119

Navajo County, quadrangles

Agathla Peak 4, 8-..--.---57, 120

Springs, Mogollon Rim-_..._...- 159

Arkansas:

Bauxite logs, Saline and Pulaski

Counties-_-_.-.-. 170

California:

Geology, Mountain Pass district,

San Bernardino County-...-...- 109

Ground water, Death Valley National

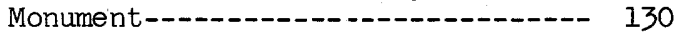

hydrologic data, Putah Creek-..- 152

levels, observation wells, Santa

Barbara County--...-..---6, 168

Ground water-streamflow, Santa Bar-

bara County, Santa Ynex River------ 158

Tocolote Tunnel area-_._._.-.- 21

Maps and charts, bastnaesite

deposits, Birthday claims, San

Bernardino Codinty-...........-. quicksilver mine area, New

Almanden-
Report

California-Continued

Maps and charts, bastnaesite deposits-Cont. rare-earth deposits, Mountain

Pass district--------.--- 110

zinc-copper, Shasta County,

Bully Hill and Rising Star

mines-..-.-. 2

Colorado:

Hydrogeology, Echo Park Reservolr

project--_- 149

Maps and charts, geologic, Gar-

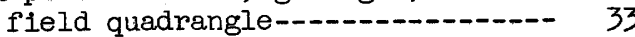

Sinbad Valley-Fischer Val-

ley anticline-..-.-.-.-. 138

photogeologic, Dolores County,

quadrangles Verdure 1, 8, 9,-63, 65

Montezuma County, quadrangles

Aneth 1, Verdure 16------58, 65

San Miguel County, quad-

rangles Verdure 1, 9--.---63, 65

Pegmatites, Larimer County, Crys-

tal Mountain district-_.....--- 154

Gunnison County, Quartz Creek

district_-_. 141

Colorado River:

Quality of water-16

Columbia River:

Tributaries, streamflow-_-_-_-- 126

Conservation:

Mineral classification, Pondera

oll field, Mont-_-_ 41

011 and gas, Elk basin, Wyo. and

Mont--.-.- 49

Water and power, Red River and

tributaries, N. Mex--- 34

Big Bottom dam site, Lewis

River, Wash--_-_-_-_-_--- 11

Engineering Geology:

Landslides, Rapid City, S. Dek---- 29

Mineralogy in dam construction---- 18

Florida:

Ground water, maps and charts,

Dade County,...levels-_-_-_----79, 80

1,000-ppm isochlor...... 78

salt-water penetration----- 78

Geochemistry:

Cobalt, in soils, field determination-----------

Natural water-...-...- 71

Sodium and potassium, in water, flame-photometer tests-_...-.-- 89

Water, Powder River basin, Wyo. and Mont--_-_- 146

Geophysics:

Electric-logging methods in

hydrology-- 


\section{Georgia:}

Wells, chloride content of water,

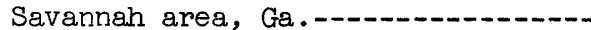

Ground water:

Dam site hydrology, Virgin Islands,

St. Croix--

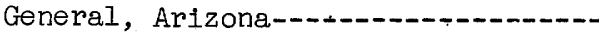

geological story of a river-.---

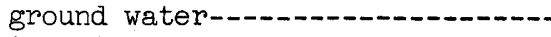

Ground Water Branch, U. S. Geo-

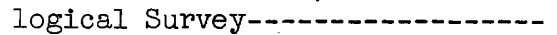

hydrologic laboratory, Lincoln,

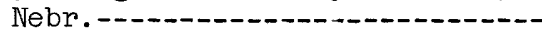

Geochemistry, brines, Dundee for-

mation--

chloride determinations, Georgia,

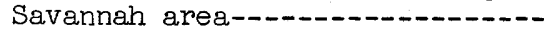

natural water--.--

quality of water, Riverton irri-

gation project, Wyo.--.-----

sodium and potassium, flame-

photometer tests-_.......-

water, Powder River basin, Wyo.

and Mont---.---

Geology, Arizona, Organ Pipe Cactus

National Monument_-_._-_._-_-_Kentucky, Calvert

ville area--

Oregon, Swann Lake-Yonna Valleys

area, Klamath County-.-.-.-.-.

South Dakota, Belle Fourche irrigation project--.-.---..--..-

Wyoming, Riverton irrigation

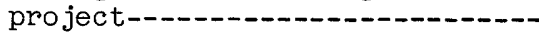

Highway engineering problems---.----

Hydrogeology, Echo Park reservoir

project, Colo.--

Hydrology, electric-logging

methods--...-. evapotranspiration determination,

Ashley Valley, Utah-..-...-..-

general-..-

permeability determination, un-

consolidated sediments.......-.

type curves-.....-.

water-level records, anal-

ysis of - 20

Hydrologic data, Putah area, Cali-

fornia---_-

Investigations, Alabama, Huntsville

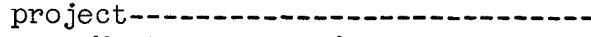

Montgomery project--

California, Tecolote tunnel pro-

ject--.-_-

Foreign assistance program-.-.--

Idaho, Michaud Flats project-----

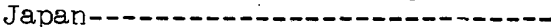

Merrimack River drainage

basin--.--

Rhode Island-.....................

Trust Territory of the Pacific---

Irrigation, effect on water

quality-.......

Levels, Arizona-_-_-

Cálifornia, Santa Barbara

County--._.-_..- 168

Putah area-_........... 152

Idaho, Minidoka County-.....-.-. 43

Oneida County-............. 106

Raft River Valley-........... 42

Maryland, West Denton area--.--- 124

New Mexico-n.
Report

Ground water-Continued

Maps and charts, Arizona, Safford Valley Irrigation

wells-_-

Florida, Dade County, 1,000 ppm

isochlor-a 78

potential salt-water pene-

tration-_..- 78

water levels_..._._._.-. 79, 80

Nebraska, Valentine National Wildlife Refuge-Ainsworth

area-_._. 148

Texas, southern, cross sections- 35

Washington, Point Misery quad-

rangle--.-.-- 135

Mining hydrology, Arizona, San

Manuel mine-..... 95

Pumps, portable, submersible unit-- 90

Pumping tests, method for plotting- 91

New Jersey, Seabrook Farms--.-- 125

Recharge, Utah, East Shore area--- 32

Texas-....... 50

Resources, California, Death Valley

National Monument_-_._-_._.-_ 130

Michigan, Alma area-_.......- 44

Nebraska-_-_-_-_-_-_-_-n--- 147

Nevada, Las Vegas Valley------- 93

New Hampshire and Massachusetts, Merrimack River drainage

basin--

North and South Dakota, Cheyenne River and Standing Rock Indian Reservations--..--_.-- 96

Pennsylvania, U. S. Naval Base,

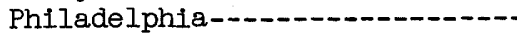

Wyoming, Horse Creek and Cherry

Creek drainage basins--.-.---

Springs, Arizona, Mogollon Rim-----

Supply, New Mexico, Red Mountain

area, effect of development--.----

Texas, La Luna---_-

West Virginia, U. S. Fish Culture

Station, White Sulphur Springs-

Tunnel hydrology:

Tecolote tunnel area--.-..--

Honduras:

Antimony, El Quezal mine-.--_---

Idaho:

Geology, Canyon-Ninemile Creeks area, Shoshone County-...-....Dry Valley quadrangle-a.

Ground water, Michaud Flats project, Power County-_-_-_-_-_-_.-. 143

Maps and charts, Johnson Creek quadrangle, Caribou County-------Mullan and vicinity quadrangle-Pottsville quadrangle--.--.---Twin Crags quadrangle---------

Ore deposits, Canyon-Ninemile Creeks area, Shoshone County--..--..-

Well records, Minidoka County----One1da County-..-... 106 Raft River Valley, Cassia County-C.-

Iowa:

Drill-core descriptions, Tete des Morts area 
Irrigation:

Withdrawals, Raft River Valley,

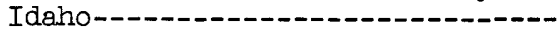

Japan:

Ground water-1..-

Kansas:

Chemical composition and stream-

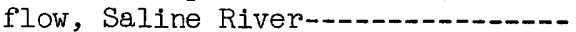

Kentucky:

Ground water, Calvert City-

Gilbertsville area-.--_-_-_-.--.---

Maine:

Bedrock survey, Passamaquoddy------ 140

Traprock, Somerset County--.---.--- 16

Maryland:

Ground water, West Denton area------

124

Massachusetts:

Geologic reconnaissance, Newton and Norwood quadrangles--.--.--.------Ground water, Merrimack River drain-

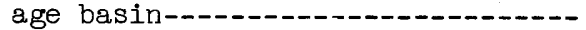

Mexico:

Phosphate deposits, Concepción del

Oro district, Zacatecas--.--_------ 131

Michigan:

Brines, Dundee formation--.---..----

Ground water, Alma area-...-.-...--

Magnetic anomaly, Bear Lake, Hough-

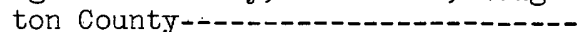

Minnesota:

Geologic map, Crosby and Ironton

area, Cuyuna Range--..--.-.-.--.--

Montana:

Geochemistry, water, Powder River

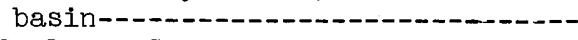

Geology, Crazy Mountain syncline-

Beartooth Mountain border-.-.-.---Nashua quadrangle-.-.-.--.-.--..-

Maps and charts, geologic, radioactivity anomalies, Jefferson City quadrangle------------------southern Elkhorn Mountains--structural contour, Pondera oil

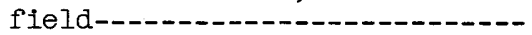
Williston basin, Fort Peck

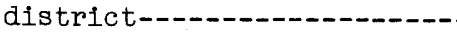

Mineral deposits, Beaverhead

County--------------

Oil and gas, Elk basin, Embar-Ten-

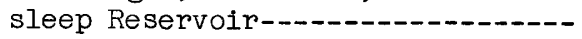

Uranium, Jefferson County--.--.-----

Nebraska:

Ground-water resources-----_-------- 147

Lincoln hydrologic laboratory--.--- 84

Map, ground-water, Valentine Wild-

life Refuge-Ainsworth area-.....-- 148

Sediments, Snake River-.......-...-- 81

Nevada:

Geology, Mount Rosa area-.-.-.-.--- 100

Ground water, The Strip, Las Vegas

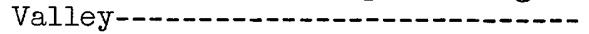

Tungsten, Victor deposit, Nye

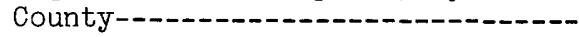

129
New Hampshire:

Ground-water resources, Merrlmack

River drainage basin-.-.-.-.-..-.....

New Jersey:

Map, aeromagnetic, Somerville quad-

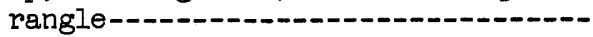

New Mexico:

Fluorspar, Zun1 Mountains, Valencia

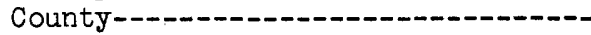

Geology, Santa Rita quadrangle,

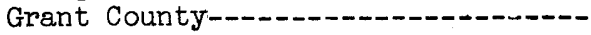

Ground water, west of Red Mountain--

Ground-water levels, annual measure-

ment----------

Manganese, Socorro--_-

New York:

Artesian observation well, Nassau

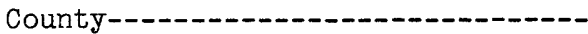

North Dakota:

Ground water, Cheyenne River and

Standing Rock Indian Reservation

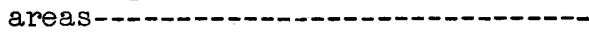

Map, glacial Lake Souris-_-_-_-_--

Oregon:

Ground-water resources, Swann Lake-

Yonna Valleys area-...-

Paleontology:

Technical index (microfilm), bibliography, paleobotanical species---: 171 Foraminifera, Cushman catalogue-- 171 Mesozoic species, North and Central America, the Caribbean----- 171 South America-.-.-.-.-.-.-.---- 171 paleobotanical species----.-.-.-- 171

Pegmatites:

Colorado, Crystal Mountain district- 154 Quartz Creek district-...-..--- 141

Pennsylvania: Ground-water resources, U. S. Naval Base, Philadelphia-........-...-.--

Permafrost:

Translations, papers by Z. A. Nersesova and G. A. Vinokurov-_-

Petrology: Heavy-mineral analysis, sedimentary rocks, Alaska--_...-

Phosphate deposits: Mexico, Concepción del Oro district, Zacatecas--_-_-_-_-_-

Phosphoria formation:

Stratigraphic sections, Idaho-----23,

Rare earth deposits:

Mountaln Pass district, California--

Rhode Island:

Ground water, survey report--......--

109

4

South Dakota:

Geology, Canning quadrangle----------

Chamberlain quadrangle-...-...-.--

Ground water, Cheyenne and Standing

Rock Indian Reservation areas------

Irrigation, Belle Fourche

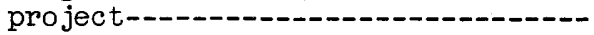

Landslides, Rapid City

4 07 12 涪 73 51 94 7 28

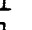

政


Surface water:

Quality, Colorado River-_-n 76

Sediments, Passamaquoddy dam

site-1.-.

Snake River, Nebraska-_._-_.- 81

total load, alluvial streams-..- 14

Streamflow: turbulence flume------------ 15

California, Santa Ynez River---- 158

Tecolote tunnel area-.--.-- 21

Relation to mineral constituents,

Saline River, Kans-_-_-_-_-_- 37

Tennessee:

Diamond-drill logs, Eve Mills zinc Texas:

area, Monroe--.----_-

Ground water, irrigation, La

Luna-...-...- 144

recharge-............. 50

sections, southern part-..---- 35

Well-core descriptions, Scurry

reef-_-.._- 133

I'rust Territory of the Pacific:

Ground-water investigations-...---

Utah:

Evapo-transpiration determination,

Ashley Valley-........ 151

Ground water, index well, Ogden

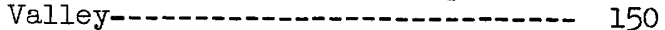

recharge, East Shore area-...- 32

Maps, base, Thompsons district,

Grand Canyon--. 45

geologic, area south of Park

City-.-- 10

Sinbad Valley-Fischer Valley

anticline--_-_-_-_-_- 138

photogeologic, Emery County,

quadrangles Stinking

Creek 11-14-.....-...-.-12, 122

San Juan County, quadrangles

Aneth 1-8_-.-.-.-. 59

Bluff $1,8,13,14 \ldots--66,121$

Carlisle $1,8,9,16 \ldots 155$
Utah-Continued

Report

Maps, photogeologic-Continued

San Juan County, quadrangles

Clay H1lls 12, 13, 15--..-40, 46, 47

Elk Ridge 1, 8, 9, 12,

$13,16-\ldots 2$

Mount Peale 5, 6,

$11-14-\ldots 156,157$

Verdure 1-14, 16-...-. 63,65

Virgin Islands:

Dam sites, St. Croix-_-_- 98

Washington:

Big Bottom dam site, Lewis

River-_-

Maps, aeromagnetic, Grays Harbor,

Pacific, Thurston, and Lewis

Counties--._- 74

Water and power:

Big Bottom dam site, Lewis River,

Wash--.--

Dam sites, St. Croix, V. I-_-_-- 98

Red River and tributaries,

N. Mex- 34

West Virginia:

Water supply, U. S. Fish Culture:

Station, White Sulphur.Springs---- 139

Wisconsin:

Drill-core descriptions, Highland

area, Wisconsin-_-_-_...-... 48

Wyoming:

Geochemistry, water, Powder River

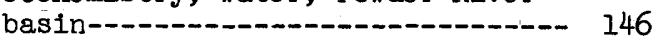

Riverton irrigation project----- 101

Ground-water resources, Horse

Creek and Cherry Creek drain-

age basins--_-_-_-_-_-_--- 8

Map, geologic, Conant Creek-

Muskrat Creek area, Fremont

County-_-_-_-_.- 153

OIl and gas, Elk basin-..-_-_.- 49

Riverton irrigation project------ 101

Titaniferous iron deposits,

Laramie Range-_-_.- 108 